Cornell University Law School Scholarship@Cornell Law: A Digital Repository

\title{
The Impact of Medical Liability Standards on Regional Variations in Physician Behavior: Evidence from the Adoption of National-Standard Rules
}

Michael Frakes

Cornell Law School

Follow this and additional works at: http://scholarship.law.cornell.edu/facpub

Part of the Health Law Commons, Law and Economics Commons, and the Torts Commons

\section{Recommended Citation}

Frakes, Michael, "The Impact of Medical Liability Standards on Regional Variations in Physician Behavior: Evidence from the Adoption of National-Standard Rules" (2013). Cornell Law Faculty Publications. Paper 927.

http://scholarship.law.cornell.edu/facpub/927 


\title{
The Impact of Medical Liability Standards on Regional Variations in Physician Behavior: Evidence from the Adoption of National-Standard Rules
}

\author{
By Michael FraKes*
}

\begin{abstract}
I explore the association between regional variations in physician behavior and the geographical scope of malpractice standards of care. I estimate a 30-50 percent reduction in the gap between state and national utilization rates of various treatments and diagnostic procedures following the adoption of a rule requiring physicians to follow national, as opposed to local, standards. These findings suggest that standardization in malpractice law may lead to greater standardization in practices and, more generally, that physicians may indeed adhere to specific liability standards. In connection with the estimated convergence in practices, I observe no associated changes in patient health. (JEL I11, I18, J44, K13)
\end{abstract}

A large literature in health economics and medicine has explored the regional practice patterns of physicians and other medical providers and has endeavored to understand (i) why some regions spend so much in the care of patients relative to other regions and (ii) whether high-spending regions generate superior health outcomes. In this paper, I explore a potential contribution to the observed disparities in care that has been suggested by leading theoretical scholars in the area-variations literature (Phelps 1992), but that has yet to be explored empirically: laws respecting the geographical nature of the standards of care employed in medical malpractice actions. In addition to shedding potentially valuable light on each of the above puzzles, this investigation may, at the same time, offer novel insight into the fundamental question of whether physicians are responsive to the specific standards expected of them under the law.

A common thread that emerges throughout those studies that have endeavored to explore the causes behind the regional variations phenomenon is the inability

\footnotetext{
*Cornell Law School, 314 Myron Taylor Hall, Ithaca, NY 14853 (e-mail: mdf96@ cornell.edu). I am grateful to Amy Finkelstein and Jon Gruber for their guidance and advice. I would also like to thank the following people for their helpful comments: Jennifer Arlen, David Autor, Ronen Avraham, Kate Baicker, Amitabh Chandra, Joe Doyle, Einer Elhauge, Arnold Epstein, Michael Greenstone, Louis Kaplow, Michelle Mello, Benjamin Roin, Meredith Rosenthal, Steve Shavell, Melissa Wasserman, and seminar participants at the American Law and Economics Association Annual Meeting and the O'Neill Institute Empirical Health Law Conference, in addition to participants at various faculty and other workshops at Harvard Law School, Cornell Law School, University of Chicago Law School, UCLA Law School, USC Gould School of Law, Emory Law School, UC Davis School of Law, William and Mary Law School, Boston College Law School, and the Health Policy and Management Department at the Harvard School of Public Health. I am grateful to Negasi Beyene, Maria Owings, and the staff at the Research Data Center at the National Center for Health Statistics for their help with the National Hospital Discharge Survey files, and to Ronen Avraham for graciously providing data on state tort laws. Funding from the National Institute on Aging, Grant Number T32-AG00186, is gratefully acknowledged.

${ }^{\dagger}$ To view additional materials, visit the article page at http://dx.doi.org/10.1257/aer.103.1.257.
} 
to explain a substantial portion of the observed variation in medical practices. ${ }^{1}$ Accounting for various socioeconomic and other factors, Baicker, Buckles, and Chandra (2006), for instance, are unable to explain about 40 percent of the regional variation in cesarean utilization rates across US counties. Interestingly, they do find that 14.8 percent of the cesarean variation is explained by certain measures of regional malpractice intensity, including the frequency and severity of malpractice awards. Those rare regional-variations studies that have addressed the role of medical liability, however, have overlooked those geographical components of malpractice law that may be most relevant to a discussion of regional practice patterns.

While tort law typically sets operable standards of care by determining what a "reasonable" person would do under similar circumstances, malpractice law generally sets standards by determining what physicians actually do. To determine what these customary standards are, traditional malpractice law turned to the behavior of physicians practicing in the same locality as the defendant. That is, physicians were expected to follow the practices applied by those around them. The application of such "locality" rules could reasonably lead to the perpetuation of divergent regional practice patterns. I explore this possibility by estimating whether procedure utilization rates in a state that uses a local standard rule converge towards the relevant national rates when the state amends its malpractice laws to require that physicians comply with national standards of care. Since the 1960s and 1970s, the majority of states have amended their substantive malpractice laws to adopt such national rules.

Online Appendix A provides more details on the evolution of malpractice standard rules. I document 16 states that abandoned the use of local standards in favor of national standards in the post-1977 period, ${ }^{2}$ along with 1 additional state (Maryland) that retreated from a previous national-standard adoption. Sixteen states currently retain some element of locality in their standard-of-care laws.

Focusing on obstetric and cardiac practices, I find evidence of regional convergence in the utilization rates of the targeted treatments and diagnostic procedures upon the abandonment of a locality rule. For instance, in the case of cesarean deliveries, I find evidence consistent with a convergence effect in which 40 percent of the gap between state and national utilization rates is closed in connection with the adoption of a national-standard rule.

This regional convergence analysis also affords an opportunity to confront the second major question raised by the regional variations phenomenon: where along the regional distribution of practices does the optimum lie? Embracing an arguably exogenous source of variation in within-state treatment rates, I find evidence that is generally consistent with a "flat-of-the-curve" story, suggesting that reductions in the investigated treatment rates may be achieved with little detriment to associated health outcomes (e.g., neonatal mortality).

\footnotetext{
${ }^{1}$ Prominent examples include Phelps and Mooney (1993), Wennberg and Cooper (1999), and Cutler and Sheiner (1999).

${ }^{2}$ Such states include New Mexico (1978), Nevada (1979), Alabama (1980), Washington, DC (1980), South Carolina (1981), Wyoming (1981), Colorado (1983), Mississippi (1983), Connecticut (1984), Oklahoma (1984), Montana (1985), West Virginia (1986), South Dakota (1988), Indiana (1992), Rhode Island (1998), and Delaware (1999).
} 
The numerous ambiguities surrounding the deterrent channel of malpractice liability have, in part, motivated a larger literature exploring the relationship between physician behavior and malpractice law. To date, empirical investigations into any such relationship have focused on evaluating the impact of malpractice laws that operate by reducing the expected consequences of medical liability-e.g., caps on noneconomic damages (see, for example, Kessler and McClellan 1996). These remedial-focused studies overlook another way in which malpractice laws may be amended in order to shape behavior: varying the manner in which the alleged actions of physicians are deemed to trigger liability in the first instance (Blumstein 2006). While the convergence analysis tells a specific story regarding the impact of the geographical components of standard-of-care rules, the convergence findings may also offer a more general contribution by demonstrating the empirical relevancy of legal standards of care themselves. ${ }^{3}$

The paper proceeds as follows. Section I discusses the impact on physician behavior of malpractice-standard rules. Sections II and III describe the data and empirical methodology. Section IV presents results of the utilization and health outcomes analyses. Section V concludes.

\section{Impact of Malpractice-Standard Rules}

Treatment utilization rates followed by local physicians may, in part, be a reflection of their idiosyncratic beliefs regarding optimal practices (Wennberg 1984). Divergence in beliefs (and thus divergence in behaviors) may perpetuate over time under an assumption that physicians prefer local sources of information (Phelps and Mooney 1993). Malpractice "locality rules" may solidify these pathways by endorsing local belief structures and by discouraging the evolution of practices. This paper effectively explores whether the abandonment of a locality rule will break these isolating forces and thereby allow or encourage physicians to deviate from the present set of divergent customs. Moreover, considering that, upon the abandonment of such rules, physicians in the affected jurisdictions now face expectations to follow the customary behaviors followed by physicians nationally, the essential hypothesis tested in this paper is that the practices of those affected physicians will indeed conform to the practices applied in other regions.

Two mechanisms may underlie a physician's response to this change in malpractice-standard laws: (i) an informational mechanism and (ii) an incentive mechanism. First, while customary locality rules may reinforce the limited information sets that are, in part, responsible for regional practice patterns, the adoption of a national-standard rule may expose local physicians to information that challenges their priors. By flowing through the liability system, this information source may be salient enough to induce physicians to update these priors and revise their behavior to be in greater accord with the rest of the country.

\footnotetext{
${ }^{3}$ While no studies to date have directly explored the relationship between the locality rule and physician behavior, several have found evidence consistent with a positive relationship between malpractice claims severity and frequency and the adoption of laws requiring the use of broader geographical standards (Waters et al. 2007; Adams and Zuckerman 1984; and Danzon 1984). While these results are not determinative of the manner in which physicians will respond to an abandonment of the locality rule, they nonetheless support an argument that a change in malpractice standard laws alters the expectations being placed upon physicians.
} 
Moreover, following the change in legal regime, physicians may face liability risks to the extent that their local practices deviate from the national standard. The channels by which physicians respond to a shift in standards may be reflective of both changes in liability fears over improperly addressing the underlying condition and changes in fears over improperly executing the associated treatment. For instance, consider an initially low-intensity treatment area. Following a nationalstandard adoption, the law may call for a more intensive treatment regime. This may be due, in part, to a heightening of previously low standards regarding when treatment should be employed under a given set of clinical circumstances, which may push physicians to increase treatment utilizations in order to avoid liability. The change in law may also amount to a reduction of previously high standards regarding the execution of the treatment, which may give physicians more freedom to explore treatment options for certain patients and likewise induce them to increase their utilization rates.

Similar mechanisms may drive physician behavior in initially high-intensity treatment areas. These mechanisms may not operate symmetrically on both ends of the regional utilization distribution, however. As such, in some empirical specifications, I allow for differential responses from each side.

\section{Data}

Data on physician behavior is from the 1977 to 2005 National Hospital Discharge Survey (NHDS) files, each of which provides a sample of inpatient discharge records from short-stay, nonfederal hospitals. The NHDS offers comprehensive utilization data covering a long enough period of time to take advantage of the rich set of reforms that occurred from the 1970s to the 1990s.

The analysis below focuses on two types of care that are less susceptible to the limitations of the NHDS - primarily, the lack of outpatient records - and that are common subjects of the medical malpractice ${ }^{4}$ and regional variations 5 literatures: obstetrics and complex cardiac care. Online Appendix B provides further details on the construction of the resulting sample and of the relevant procedure rates, in addition to the rationale behind the selection of the targeted procedures.

Obstetric Utilization Measures.-This study places particular emphasis on the decision to deliver a child via cesarean section. The primary specifications base the dependent variable on state-year cesarean rates that are risk-adjusted for maternal age and race and for the incidence of breech presentation, multiple delivery, or previous cesarean delivery. Cesareans are heavily performed in the presence of these latter risk factors, implicating a concern that the within-state variation in cesarean rates in the NHDS sample may be too sensitive to variations in the incidence of these relatively nondiscretionary circumstances (discussed further in

\footnotetext{
${ }^{4}$ See, for example, Currie and MacLeod (2008) and Kessler and McClellan (1996).

${ }^{5}$ See, for example, Chandra and Staiger (2007) and Baicker, Buckles, and Chandra (2006).
} 
online Appendix C). ${ }^{6}$ I also consider specifications that test for convergence in the rates of vaginal births after previous cesarean deliveries. 7

Cardiac: Treatment Measures.-Next, I consider the care administered to patients with coronary artery disease. I model this care as a choice between no intervention and intensive intervention, as represented by the use of coronary artery bypass grafts $(\mathrm{CABG})$ or percutaneous transluminal coronary angioplasties (PTCA). Alternatively, I include cardiac catheterizations on this list, treating catheterizations as a marker for intensive care (Chandra and Staiger 2007).

Cardiac: Diagnostic Measures.-Diagnostic utilization has been found to be particularly sensitive to malpractice pressures. ${ }^{8}$ The use of inpatient-only data sources, however, represents an especially sensitive problem for an analysis of the factors contributing to diagnostic utilization, an area of care with a considerable outpatient component. I take two approaches in surmounting these difficulties. First, I focus on the subsample of patients admitted with a primary diagnosis of acute myocardial infarction (AMI) and consider the use of either of the following diagnostic tools: cardiac catheterizations or echocardiograms. ${ }^{9}$ This approach softens sample selection concerns that might arise from the lack of outpatient records, given that heart attacks represent a situation in which affected patients will almost always seek hospitalization. Second, I consider a utilization rate of cardiac catheterizations across all patients-i.e., not simply primary-AMI patients. Relative to other diagnostic procedures, catheterizations are particularly invasive and are frequently performed in an inpatient setting. They are thus arguably amendable to an analysis that relies only on inpatient records. ${ }^{10}$

Descriptive Statistics.-Table 1 provides the means and standard deviations for the key variables employed in the analysis below.

\section{Empirical Methodology}

\section{A. Utilization Specifications}

To explore whether physicians begin to follow the practices applied nationally upon the adoption of a national-standard rule, I test whether state utilization rates for the procedures indicated above converge towards their respective national mean

\footnotetext{
${ }^{6}$ Online Appendix B provides further details on the rationale behind this construction. Those specifications that use a sample of individual deliveries base the dependent variable on the incidence of cesarean delivery and include controls for these highly determinative risk factors. In alternative specifications estimated in online Appendix C, I follow the Agency for Healthcare Research and Quality's definition of a "primary" cesarean rate, which excludes deliveries with those same highly determinative risk factors from the cesarean rate calculation.

${ }^{7}$ To lessen sample selection concerns arising from the fact that the sample used here (cesareans) changes in composition in association with national-standard rules, I risk-adjust the rates of vaginal births after cesarean delivery for a range of risk factors (see online Appendix B).

${ }^{8}$ See, for example, Baicker, Fisher, and Chandra (2007).

${ }^{9}$ These measures represent the most common invasive and noninvasive diagnostic tools, respectively, used on primary AMI patients in the NHDS sample. The area variations literature often invokes cardiac catheterization as the representative example of a diagnostic imaging procedure. See, for example, Wennberg and Cooper (1999).

${ }^{10}$ In calculating general cardiac catheterization rates, I scale state-year catheterization counts by the total number of AMIs in the state-year cell.
} 
Table 1 -Means and Standard Deviations of Selected Variables

\begin{tabular}{|c|c|c|}
\hline & $\begin{array}{c}\text { Mean } \\
(1)\end{array}$ & $\begin{array}{l}\text { Percentage absolute } \\
\text { deviation between state } \\
\text { and national mean } \\
\text { (2) }\end{array}$ \\
\hline National standard-of-care law & $\begin{array}{c}62.93 \\
(48.32)\end{array}$ & - \\
\hline $\begin{array}{l}\text { Cesarean section rate } \\
\text { (standardized, percent) }\end{array}$ & $\begin{array}{l}22.32 \\
(4.87)\end{array}$ & $\begin{array}{l}10.08 \\
(9.47)\end{array}$ \\
\hline $\begin{array}{l}\text { Vaginal birth after cesarean rate } \\
\text { (percent) }\end{array}$ & $\begin{array}{c}20.40 \\
(13.75)\end{array}$ & $\begin{array}{c}36.52 \\
(47.69)\end{array}$ \\
\hline $\begin{array}{l}\text { Cardiac treatment rate: CABG or PTCA } \\
\text { (normalized by state-year AMI count) }\end{array}$ & $\begin{array}{c}0.94 \\
(0.57)\end{array}$ & $\begin{array}{c}41.49 \\
(36.44)\end{array}$ \\
\hline $\begin{array}{l}\text { Cardiac treatment rate: CABG, PTCA, or cardiac cath. } \\
\text { (normalized by state-year AMI count) }\end{array}$ & $\begin{array}{c}1.83 \\
(0.81)\end{array}$ & $\begin{array}{c}31.94 \\
(32.21)\end{array}$ \\
\hline $\begin{array}{l}\text { Cardiac cath. rate } \\
\text { (normalized by state-year AMI count) }\end{array}$ & $\begin{array}{c}1.50 \\
(0.68)\end{array}$ & $\begin{array}{c}31.93 \\
(33.80)\end{array}$ \\
\hline $\begin{array}{l}\text { Rate of cardiac cath. or echocardiogram within primary } \\
\text { AMI subsample (percent) }\end{array}$ & $\begin{array}{c}41.09 \\
(18.66)\end{array}$ & $\begin{array}{l}26.23 \\
(29.21)\end{array}$ \\
\hline $\begin{array}{l}\text { Rate of cardiac cath. within primary AMI subsample } \\
\text { (percent) }\end{array}$ & $\begin{array}{c}35.70 \\
(19.15)\end{array}$ & $\begin{array}{c}34.56 \\
(33.25)\end{array}$ \\
\hline Five-minute Apgar score & $\begin{array}{c}8.97 \\
(0.13)\end{array}$ & $\begin{array}{c}0.85 \\
(0.88)\end{array}$ \\
\hline $\begin{array}{l}\text { "Good" five-minute Apgar score } \\
\text { (percent) }\end{array}$ & $\begin{array}{l}98.4 \\
(0.40)\end{array}$ & $\begin{array}{c}0.23 \\
(0.23)\end{array}$ \\
\hline $\begin{array}{l}28 \text { day neonatal mortality rate } \\
\text { (per } 100 \text { live births) }\end{array}$ & $\begin{array}{c}0.65 \\
(0.22)\end{array}$ & $\begin{array}{l}16.86 \\
(16.17)\end{array}$ \\
\hline $\begin{array}{l}\text { Predicted probability of cesarean } \\
\text { Delivery (cesarean sample, percent) }\end{array}$ & $\begin{array}{l}61.64 \\
(6.88)\end{array}$ & - \\
\hline
\end{tabular}

Notes: Standard deviations are in parentheses. Treatment utilization measures are from a sample of 1,230 state-year cells from the 1977-2005 NHDS files. The national-standard measure is calculated over the same set of state-year cells. Five-minute Apgar scores and neonatal mortality rates are from the 1978-2004 Natality Detail files and the 1977-2004 Vital Statistics Mortality files, respectively. The predicted cesarean probability measure is from the 1979-2005 NHDS files. Statistics are weighted by the relevant number of deliveries associated with each state-year cell (obstetric measures) or the relevant number of primary AMI discharges associated with each cell (cardiac measures).

rates as states adopt such rules. For the purposes of illustration, I demonstrate the empirical methodology for the case of the cesarean delivery decision. I begin by estimating the following specification, weighting each observation by the number of deliveries in each state-year cell:

$$
\begin{aligned}
C S \_G A P_{s, t}= & \alpha+\gamma_{s}+\boldsymbol{\lambda}_{t}+\boldsymbol{\varphi}_{s, t}+\beta_{1} N S_{s, t}+\beta_{2} N S_{s, t+2} \\
& +\boldsymbol{\beta}_{3} \mathbf{X}_{s, t}+\boldsymbol{\beta}_{4} \mathbf{Z}_{s, t}+\boldsymbol{\beta}_{5} \mathbf{O}_{s, t}+\varepsilon_{s, t},
\end{aligned}
$$

where $s$ indexes state and $t$ indexes year; $N S_{s, t}$ represents an indicator for a nationalstandard law; $\mathbf{X}_{s, t}$ represents mean incidence rates within the NHDS delivery subsample of various maternal and hospital characteristics; ${ }^{11}$ and $\mathbf{Z}_{s, t}$ represents

\footnotetext{
${ }^{11}$ Such characteristics include: mother's age (15-19, 20-24, 25-29, 30-34, 35-39, and 40+ years old); mother's race (white, black, and other); mother's insurance status (private, government, no insurance, and other); hospital
} 
certain additional state-year factors. ${ }^{12}$ State fixed effects, $\gamma_{s}$, and year fixed effects, $\lambda_{t}$, control for fixed differences across states and across years, respectively. Statespecific linear time trends are captured by $\varphi_{s, t}$, which control for slowly moving correlations between physician behavior in a state and the adoption of a nationalstandard law. Controls for the presence of the following tort reforms are included in $\mathbf{O}_{s, t}$ : damage caps (noneconomic, punitive, and total), collateral source-rule reforms, and other "indirect" reforms, a residual category that is specified according to Kessler and McClellan (1996).13 Representing a measure of closeness between state and national cesarean rates, $C S \_G A P_{s, t}$ is calculated as the absolute value of the difference between the state and national cesarean rate, normalized by the national rate. ${ }^{14}$

The coefficient of interest is represented by $\beta_{1}$, which identifies the extent to which the adoption of a national-standard law is associated with a convergence between state and national behavior. Of course, the specified dependent variable may also capture sources of mean revision in regional cesarean rates, which poses a concern that $\beta_{1}$ spuriously reflects a differential level of mean revision between treatment and control states. I test for this possibility by including a "lead" of the nationalstandard indicator, $N S_{s, t+2}$, in the base specifications. This variable indicates, at time $t$, a state's national-standard status at time $t+2$. A negative estimate for $\beta_{2}$ would suggest that the convergence associated with such laws emerged in the period leading up to their adoptions and thus may not be reflective of a true policy response. In other specifications, I estimate an even more dynamic specification that includes a range of lead indicator variables. ${ }^{15}$

The above approach parameterizes convergence in behavior through the construction of the dependent variable. In an alternative approach, I specify the dependent variable as the individual incidence of cesarean delivery and capture malpractice-induced convergence by specifying a modified national-standard variable, $M O D \_N S$, that switches (i) from 0 to 1 upon the adoption of a nationalstandard law for those states that begin with standardized cesarean rates below the national average (and for which the adoption is hypothesized to lead to an increase in utilization); and (ii) from 1 to 0 upon the adoption of a national-standard law for those states that begin with above-average rates (and for which the adoption is

\footnotetext{
bed size (0-100, 100-200, 200-300, 300-500, and 500+ beds); and hospital ownership type (proprietary, nonprofit, and government).

${ }^{12}$ These characteristics include the prevailing OB/GYN concentration rates and fertility rates. Data on physician population counts are from the American Medical Association administrative records and were obtained from the Area Resource File (ARF). Fertility rates are calculated according to Gruber and Owings (1996) as the number of births per population and come from the Vital Statistics Natality files (also obtained via the ARF).

${ }^{13}$ For example, an "indirect" reform includes a limitation on joint and several liability. Data on tort reforms is from the Database of State Tort Law Reforms (2nd) compiled by Ronen Avraham.

${ }^{14}$ In calculating this dependent variable for each state and year, the national rate is adjusted accordingly to remove the contribution of the NHDS records from the relevant state-year cell.

${ }^{15}$ I follow Acemoglu and Finkelstein (2008) in testing for differential trends in the preadoption period through the estimation of specifications that include a single preperiod lead indicator, along with dynamic specifications that include several preperiod leads. In those that include just one lead, I follow Gruber and Hungerman (2008) in observing behavior in the two-year period leading up to the reform, providing enough time to sufficiently assess prereform treatment rates.
} 
hypothesized to lead to a decrease in utilization). 16 Accordingly, I estimate the following specification using the full sample of individual deliveries:

$$
\begin{aligned}
U_{i, s, t}= & \alpha+\gamma_{s}+\lambda_{t}+\varphi_{s, t}+\boldsymbol{\beta}_{1} \mathbf{X}_{i, s, t}+\boldsymbol{\beta}_{2} \mathbf{Z}_{s, t}+\boldsymbol{\beta}_{3} \mathbf{O}_{s, t} \\
& +\beta_{4} M O D \_N S_{s, t}+\beta_{5} M O D \_N S_{s, t+2}+\varepsilon_{i, s, t},
\end{aligned}
$$

where $\mathbf{X}_{i, s, t}$ now represents the individual incidence of the various maternal and hospital characteristics; $U_{i, s, t}$ indicates a cesarean delivery for individual $i$ in state $s$ and year $t$. A convergent response to the adoption of a national-standard law is identified by a positive estimate of the coefficient of the modified indicator. ${ }^{17}$

Each of the above specifications allows simultaneously for convergence to occur from both ends of the regional utilization distribution. I also consider a set of specifications that estimate separate physician responses for each side of this distribution, thereby relaxing any assumption of symmetry. In a final approach, which likewise does not assume a symmetrical response, I estimate the following:

$$
\begin{aligned}
U_{i, s, t}= & \alpha+\gamma_{s}+\lambda_{t}+\varphi_{s, t}+\beta_{1} \mathbf{X}_{i, s, t}+\boldsymbol{\beta}_{2} \mathbf{Z}_{s, t}+\beta_{3} \mathbf{O}_{s, t} \\
& +\beta_{4} B_{E L O W}+\beta_{5} N S_{s, t}+\beta_{6} B E L O W_{s} \times N S_{s, t}+\varepsilon_{i, s, t}
\end{aligned}
$$

where $B E L O W$ is an indicator for a state with an initially low cesarean rate. The coefficient of $\beta_{5}$ in this interaction specification can effectively be interpreted as the association between national-standard laws and cesarean rates for states with initially above-average cesarean rates (i.e., when $B E L O W=0$ ). For states with initially below average rates $(B E L O W=1)$, this same association can effectively be captured by the sum of $\beta_{5}$ and $\beta_{6}$. This approach provides an additional way to observe the potential two-sided impact of national-standard laws.

\section{B. Health Outcomes Specifications}

I next evaluate whether the shifts in treatment rates that result from the adoption of national-standard laws are associated with corresponding shifts in health outcomes. In addition to providing an evaluation of the consequences of these adoptions, this analysis facilitates a more general exploration into the returns associated with increases in the intensity of regional practices.

\footnotetext{
${ }^{16}$ I allocate each treatment state to the relevant group-initially above or initially below the national average - based on its relation to the national average in the period leading up to the reform. The sign of the relationship between state and national rates is quite stable throughout the sample. In virtually every treatment state, the state cesarean rate remains consistently on one side of the national average from the beginning of the sample period until the time of adoption.

${ }^{17}$ I estimate this relationship using a linear probability model; however, the results are robust to the use of a logit model. To address concerns over small-sample variation in the occurrence of previous-cesarean, breech, or multiple deliveries, I control for the incidence of these factors.
} 
Marginal Appropriateness.-I begin by testing for evidence of regional "triage"-i.e., as regions increase their cesarean rates, are the marginal mothers receiving cesareans becoming less and less appropriate for cesarean delivery? A finding of this nature would be consistent with a story of diminishing returns (in patient health) to increases in regional cesarean intensities.

For these purposes, I test, via a selection effect, whether an increase in the proportion of mothers receiving cesareans in a region leads to a reduction in the average cesarean-appropriateness level among mothers receiving cesareans in that region. The implication of any such negative impact is that the marginal cesarean mothers have an increasingly below-average case mix for cesareans in that region-i.e., a diminishing need for cesareans. To parameterize the appropriateness level for each delivery, I calculate the relevant mother's predicted probability of receiving a cesarean section, $P P C_{i, s, t}$, using fitted values of a logit model (estimated annually) of the incidence of cesarean delivery on a set of individual risk factors and complications. ${ }^{18}$ I then estimate the following:

$$
\begin{aligned}
M E A N \_C S \_P P C_{s, t}= & \alpha+\gamma_{s}+\boldsymbol{\lambda}_{t}+\boldsymbol{\varphi}_{s, t}+\zeta \ln \left(C S \_R A T E_{s, t}\right) \\
& +\boldsymbol{\beta}_{1} \mathbf{X}_{s, t}+\boldsymbol{\beta}_{2} \mathbf{Z}_{s, t}+\boldsymbol{\beta}_{3} \mathbf{O}_{s, t}+\varepsilon_{s, t},
\end{aligned}
$$

where $\boldsymbol{\gamma}_{s}, \boldsymbol{\lambda}_{t}, \boldsymbol{\varphi}_{s, t}, \mathbf{X}_{s, t}, \mathbf{Z}_{s, t}$, and $\mathbf{O}_{s, t}$ are defined as in specification (1) above; $M E A N \_C S \_P P C_{s, t}$ represents the average of the individual predicted cesarean probabilities, $P P C_{i, s, t}$, among the cesareans performed in state $s$ in year $t$. The natural log of the area cesarean rate is represented by $\ln \left(C S \_R A T E_{s, t}\right) \cdot 19$

The estimated coefficient of the logged cesarean rate, $\zeta$, allows for a test of the presence of regional triage in cesarean practices. As suggested by Gruber, Levine, and Staiger (1999), this estimate also identifies the magnitude of the gap between the PPC of the marginal cesarean mother and that of the average cesarean mother. To account for endogeneity concerns, ${ }^{20}$ I estimate the above specification using two-stage least squares (2SLS), instrumenting the state-year cesarean rate with the modified national-standard law, which, as above, is constructed so as to identify an increase in cesarean rates upon its adoption. ${ }^{21}$

Average Neonatal Outcomes.-While evidence of triage may be suggestive of diminishing returns to regional cesarean intensities, this evidence alone does not

\footnotetext{
${ }^{18}$ This approach follows Baicker, Buckles, and Chandra (2006) and Chandra and Staiger (2007). The set of risk factors and complications used in this calculation are listed in online Appendix B.

${ }^{19}$ To alleviate concerns over state-year shocks in the incidence of the various risk factors comprising the PPC calculation (which may otherwise confound the identification of the intended selection effect), I follow Chandra and Staiger (2007) and risk-adjust $C S \_R A T E_{s, t}$ for the state-year incidences of such factors (in addition to riskadjusting for maternal age and race).

${ }^{20}$ While the ordinary least squares estimates account for fluctuations in the incidence of the relevant risk factors, an instrumental variables approach may nonetheless appease residual concerns that cesarean rates are correlated with unobservable determinants of the case mix of cesarean mothers. For instance, if medical or technological capabilities improve within a state, this could impact both the intensive treatment rate followed and the level and quality of preventive care received by patients, which could generally impact their case mix upon delivery.

${ }^{21}$ Similar results are derived when estimating separate 2 SLS specifications for initially below-average cesarean states and initially above-average cesarean states and using unmodified national-standard indicators as the instrument. The utilization analysis below confirms the validity of the first-stage relationship between national-standard laws and cesarean rates.
} 
indicate that regions have exhausted those returns. As such, I next explore whether the changes in regional cesarean rates resulting from national-standard laws are associated with corresponding changes in average delivery outcomes. This latter approach is of course limited by the availability of data on relevant health outcomes, which are focused on mortality-related measures. Emphasizing the clinical appropriateness for cesarean delivery, the triage analysis, on the other hand, offers insight that is potentially suggestive (though indirectly) of the relationship between cesarean rates and a broader range of health outcomes.

For the purposes of a direct outcomes analysis, I estimate a specification analogous to that of equation (1) and test whether the adoption of national-standard laws are associated with a convergence in state neonatal outcome means toward national means. ${ }^{22}$ To the extent that cesarean rates are associated with average health outcomes, it would be reasonable to expect that any convergence in cesarean rates stemming from national-standard laws would be accompanied by a convergence in regional means of various neonatal outcomes. ${ }^{23}$ The outcome measures investigated include five-minute infant Apgar scores ${ }^{24}$ and 28-day neonatal mortality rates. Data on neonatal outcomes are from the 1978-2004 Natality Data and the 1977-2004 Mortality Data, each from the National Vital Statistics System.

\section{Results}

\section{A. Utilization Analysis}

Cesarean Results: Aggregated State-Year Specifications._-Panel A of Table 2 presents results for the cesarean specifications indicated in equation (1) above. ${ }^{25} \mathrm{I}$ find that a state's abandonment of a locality rule and adoption of a national-standard rule is associated with a 4.1 percentage point reduction in the absolute percentage deviation between the state's standardized cesarean rate and the national rate (column 1). This estimate amounts to a roughly 40 percent reduction in the gap between the state and national rate. The estimated coefficient of the national-standard dummy remains nearly unchanged (with slight increases in absolute magnitude) with the inclusion of state-year controls (column 2), covariate tort laws (column 3$)^{26}$, and state-specific linear time trends (column 4).

\footnotetext{
${ }^{22}$ The health outcomes specifications include state-year demographic controls for the means of various age, race, and education categories from the mothers included in the Natality records, in addition to controls for the area fertility rate and $\mathrm{OB} / \mathrm{GYN}$ concentration rate and for the average hospital bed sizes per population of the state-year cell (each of which are obtained from the ARF).

${ }^{23}$ I do not present results from an instrumental-variables specification analogous to that of the triage analysis, given the lack of a data source with consistent measures of both cesarean rates and neonatal outcomes over a period of time long enough to capture sufficient variation in national-standard laws (cesareans are only identified in the Natality files in the post-1988 period).

${ }^{24}$ Given on a scale from 0 to 10 , Apgar tests are designed to assess the health of a newborn infant and to determine the need for resuscitative efforts.

${ }^{25}$ Results are presented in percentage terms. All coefficients and standard errors presented in the regression tables are multiplied by 100. Standard errors are clustered at the state level to allow for arbitrary within-state correlations of the error structure (Bertrand, Duflo, and Mullainathan 2004).

${ }^{26}$ The addition of the covariate tort laws changes the coefficient from -4.67 to -4.64 , demonstrating the insensitivity of the findings to the incidence of additional tort laws. The correlation coefficient between the national-standard indicator and the additional tort laws is as follows: noneconomic damage caps $(0.02)$, total damage caps $(0.01)$, punitive damage caps $(-0.04)$, collateral source rule reforms $(-0.19)$, and the indirect tort law indicator $(0.24)$.
} 
Table 2-Relationship between National-Standard Laws and the Percentage Absolute Deviation between State and National Obstetric Treatment Rates

\begin{tabular}{|c|c|c|c|c|c|}
\hline & (1) & $(2)$ & (3) & (4) & $(5)$ \\
\hline \multicolumn{6}{|c|}{ Panel A. Dependent variable: percentage absolute deviation between state and national cesarean rates (standardized) } \\
\hline \multicolumn{6}{|c|}{ Coefficient of national-standard law dummy } \\
\hline Two-year lead dummy & $\begin{array}{c}-0.14 \\
(3.82)\end{array}$ & $\begin{array}{c}-0.41 \\
(3.20)\end{array}$ & $\begin{array}{c}-0.59 \\
(3.12)\end{array}$ & $\begin{array}{c}0.10 \\
(2.40)\end{array}$ & - \\
\hline Contemporaneous dummy & $\begin{array}{c}-4.09 * \\
(2.17)\end{array}$ & $\begin{array}{c}-4.67 * * \\
(2.26)\end{array}$ & $\begin{array}{c}-4.64 * \\
(2.33)\end{array}$ & $\begin{array}{c}-4.91 * * \\
(1.91)\end{array}$ & $\begin{array}{c}-4.87 * * * \\
(1.47)\end{array}$ \\
\hline Observations & 1,215 & 1,215 & 1,215 & 1,215 & 1,215 \\
\hline \multicolumn{6}{|c|}{ Panel B. Dependent variable: percentage absolute deviation between state and national VBAC (standardized) rates } \\
\hline \multicolumn{6}{|c|}{ Coefficient of national-standard law dummy } \\
\hline Two-year lead dummy & $\begin{array}{l}-0.45 \\
(14.30)\end{array}$ & $\begin{array}{c}2.22 \\
(11.46)\end{array}$ & $\begin{array}{c}1.43 \\
(11.16)\end{array}$ & $\begin{array}{c}6.00 \\
(6.16)\end{array}$ & - \\
\hline Contemporaneous dummy & $\begin{array}{c}-18.52 * \\
(10.61)\end{array}$ & $\begin{array}{c}-12.12 \\
(11.13)\end{array}$ & $\begin{array}{r}-11.05 \\
(9.21)\end{array}$ & $\begin{array}{c}-13.90 \\
(10.41)\end{array}$ & $\begin{array}{r}-11.49 \\
(8.84)\end{array}$ \\
\hline Observations & 1,191 & 1,191 & 1,191 & 1,191 & 1,191 \\
\hline State-year controls? & No & Yes & Yes & Yes & Yes \\
\hline Additional tort laws? & No & No & Yes & Yes & Yes \\
\hline State-specific linear trends? & No & No & No & Yes & Yes \\
\hline
\end{tabular}

Notes: Robust standard errors corrected for within-state correlation in the error term are reported in parentheses. All regressions include state and year fixed effects and are weighted by the number of deliveries used to form the cesarean utilization rate denominators (panel A) or the number of previous cesarean deliveries used to form the VBAC utilization rate denominators (panel B). Utilization data is from the NHDS.

*** Significant at the 1 percent level.

** Significant at the 5 percent level.

* Significant at the 10 percent level.

The estimated convergence associated with national-standard adoptions is of roughly the same size as the underlying level of convergence observed over the entire 28-year sample period for the nontreated sample (the sample of control states and preadoption years from treatment states). ${ }^{27}$ This suggests that it is unlikely that the estimated impact of national-standard laws is merely reflective of a spurious mean-reversion differential between treatment and control states. ${ }^{28}$

In further support of this point, I find that in each of columns 1-4 of Table 2, the estimated coefficient of the two-year lead indicator for the adoption of a nationalstandard law is statistically insignificant and nearly 0 in magnitude-e.g., 0.10 in column 4. Similarly, in columns 1-4 of Table 6, I estimate a richer dynamic specification that includes one-, two-, and three-year lead indicators. The coefficient of each such lead indicator is small in magnitude and statistically indistinguishable from 0 . Moreover, as indicated by the $p$-value of the $F$-statistics reported in Table 6 , the lead coefficients are collectively indistinguishable from 0 . As such, there is no

\footnotetext{
${ }^{27}$ Dividing the nontreated sample into six periods, each representing five-year increments, I find that the percentage absolute deviation between state and national cesarean rates is, relative to the first period, lower in the second-sixth periods by $1.64,2.79,1.33,3.02$, and 4.43 percentage points. Between the first and last actual sample years, this spread is slightly larger at 6 percentage points.

${ }^{28}$ Less confidence would likely be had, for instance, if the estimated 4 percentage-point reduction in the dependent variable following national-standard adoptions represented the difference between an average convergence of 20 percentage points in treatment states and an average convergence of 16 percentage points in control states.
} 


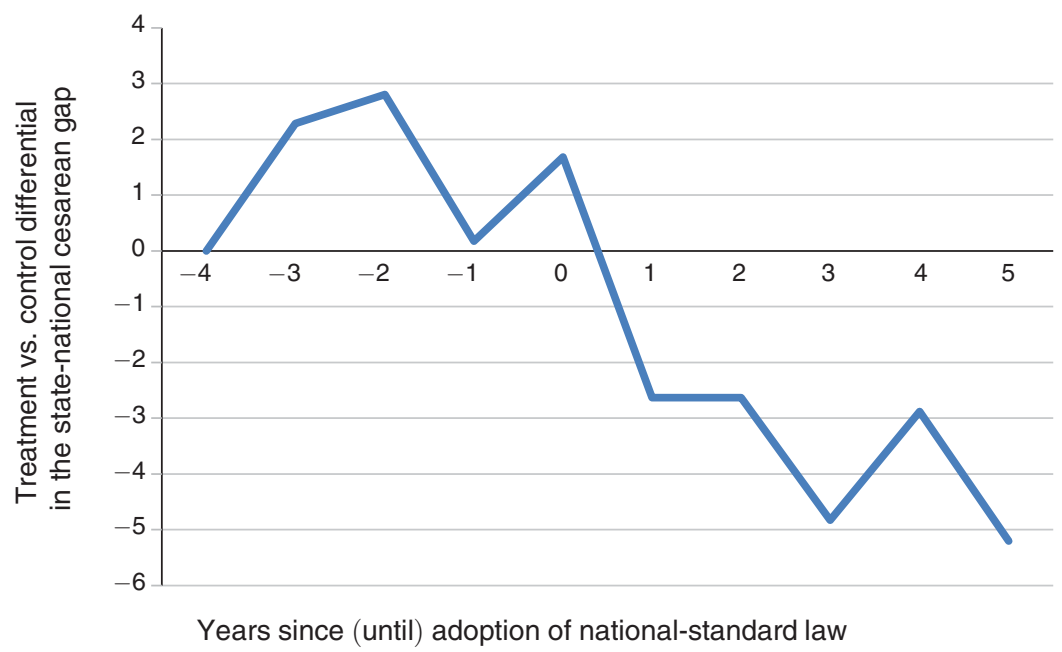

Figure 1. Dynamic Cesarean Specification Results

\begin{abstract}
Notes: This graph presents regression results from a specification that includes four-, three-, two-, and one-year lagged dummies and four-, three-, two-, and one-year lead dummies for national-standard rules. Each point draws on the estimated coefficients and reflects the change over time in the percentage absolute deviation between state and national cesarean rates, where time is defined with reference to the years prior to and subsequent to nationalstandard adoptions. The period of time prior to the fourth year before such adoptions represents the reference group (with a value set at 0 ). The specifications include the full set of state fixed effects, year fixed effects, state-specific linear time trends, and state-year controls. Cesarean data is from the NHDS.
\end{abstract}

evidence to suggest that the estimated convergence in regional cesarean rates materialized in the preadoption period.

Figure 1 plots results from a dynamic specification that includes one-, two-, three-, and tour-year lead and one-, two-, three-, and four-year lagged dummy variables for the incidence of a national-standard law. The plotted line reflects a time trend of the differential between treatment and control states in the percentage absolute deviation between state and national cesarean rates, where time is not measured in calendar years but instead with reference to the point of adoption of nationalstandard laws. This figure provides no evidence to suggest that the negative effect of national-standard rules emerged in the preadoption period. This effect, however, does emerge relatively soon following their adoption and intensifies slightly (in aggregation) over time.

In online Appendix C, I demonstrate the robustness of the above findings to a range of specification checks, including the use of a randomization inference approach, the systematic one-by-one dropping of each treatment state from the specification, and the inclusion of certain additional covariates (e.g., HMO penetration rates). As a falsification exercise, I also demonstrate the lack of a relationship between national-standard laws and convergence in the rates of various nondiscretionary medical events (e.g., AMI admissions) with respect to which one would not expect a sensitivity to the prevailing legal regime.

Cesarean Results: Individual Delivery Specifications.-In columns 1 and 2 of Table 3, I estimate a positive relationship between the incidence of cesarean delivery and the adoption of a national-standard law for those states with initially low 
TABle 3-Relationship BetweEn National-STANDARd LaWs AND the Individual LiKelihood of Cesarean Delivery

\begin{tabular}{|c|c|c|c|c|c|}
\hline & \multirow{2}{*}{$\begin{array}{c}\text { States with } \\
\begin{array}{c}\text { below-average } \\
\text { rates }\end{array} \\
(1)\end{array}$} & \multirow{2}{*}{$\begin{array}{c}\begin{array}{c}\text { States with } \\
\text { above-average } \\
\text { rates }\end{array} \\
(2)\end{array}$} & \multicolumn{3}{|c|}{$\begin{array}{c}\text { Entire sample of states } \\
\text { (above and below } \\
\text { average rates) }\end{array}$} \\
\hline & & & (3) & (4) & $(5)$ \\
\hline $\begin{array}{l}\text { National-standard (NS) law } \\
\text { dummy }\end{array}$ & $\begin{array}{l}1.01 * \\
(0.60)\end{array}$ & $\begin{array}{l}-2.21^{* *} \\
(1.04)\end{array}$ & $\begin{array}{c}-1.90 * \\
(1.00)\end{array}$ & - & - \\
\hline NS law $\times$ below average state & - & - & $\begin{array}{l}2.75^{* *} \\
(1.14)\end{array}$ & - & - \\
\hline Modified NS law dummy & - & - & - & $\begin{array}{l}1.13^{* *} \\
(0.52)\end{array}$ & $\begin{array}{l}1.15^{* *} \\
(0.55)\end{array}$ \\
\hline $\begin{array}{l}\text { Modified NS law dummy: } \\
\text { two-year lead }\end{array}$ & - & - & - & - & $\begin{array}{c}-0.04 \\
(0.66)\end{array}$ \\
\hline Observations & 203,664 & 313,985 & 517,739 & 517,739 & 517,739 \\
\hline
\end{tabular}

Notes: Robust standard errors corrected for within-state correlation in the error term are reported in parentheses. All regressions include state and year fixed effects and a set of individual controls, state-year controls, and state-specific linear time trends. The regression in column 3 also includes a separate dummy variable indicating whether the state has an initially below-average cesarean rate (coefficient omitted). Utilization data is from the NHDS.

*** Significant at the 1 percent level.

** Significant at the 5 percent level.

* Significant at the 10 percent level.

cesarean rates and a corresponding negative relationship for those states with initially high rates. ${ }^{29}$ As such, I find evidence consistent with a two-sided convergent effect. ${ }^{30}$ In column 3 , I estimate the specification indicated in equation (3), which effectively combines the approaches of columns 1 and 2. These findings suggest that for states with initially above average cesarean rates $(B E L O W=0)$, national-standard laws are associated with a 1.9 percentage point reduction in cesarean rates. The coefficient of the interaction term suggests that this association is 2.8 percentage points higher for initially low-intensity areas, in which case national-standard laws are associated with a roughly 0.9 percentage-point increase in cesarean rates for such areas. These results are likewise consistent with a two-sided convergent response to national-standard laws.

\footnotetext{
${ }^{29}$ To provide meaningful comparison groups, I allocate control groups to one of these two sets of states based on the sign of the relationship between their cesarean rate and the national average over the first few years of the sample, though the results are robust to an approach that includes every control state in each of these separate samples. In those specifications that require a division of the sample into states with initially low and initially high rates, I exclude discharges from Maryland, which repealed a previously enacted reform. While this repeal may lead to a divergence away from the national mean in light of the fact that impacted physicians may no longer be expected to comply with changing national practices, there is no firm reason to expect that this divergence will occur in one direction over the other. In any event, the results remain essentially unchanged when I include Maryland and assume that its cesarean rates will diverge from the national mean in the same direction of its deviation from that mean at the time of repeal.

${ }^{30}$ These specifications address concerns over state-year shocks in the incidence of those risk factors that almost always lead to cesarean deliveries (e.g., breech presentation) by including controls for the individual incidence of such factors. I obtain an identical set of results when I include a single control for the individual delivery's predicted probability of cesarean section, which accounts for an even broader array of risk factors. Nearly identical results are also obtained from a specification that includes separate controls for each of the risk factors involved in the PPC calculation (though these latter approaches exclude 1977 and 1978 given limited risk factor data).
} 
Finally, in column 4 (which likewise effectively combines the approaches of columns 1 and 2), I estimate the specification indicated in equation (2) above and find a roughly one percentage point increase in the incidence of cesarean delivery in association with the modified national-standard indicator, which is likewise consistent with a convergent effect in which nearly 40 percent of the average gap between state and national cesarean rates is closed upon the abandonment of a substantive locality rule. Moreover, consistent with the aggregated state-year specifications, the estimated coefficient for the 2 year lead indicator for the modified national-standard variable is insignificant and nearly 0 in magnitude.

Vaginal Birth after Cesarean Delivery (VBAC) Results.-Panel B of Table 2 presents results from the VBAC specifications. In the baseline specification, I estimate an 18.5 percentage-point reduction in the percentage absolute deviation between state and national VBAC rates (with no corresponding difference in the 2-year preperiod), consistent with a convergence effect in which roughly 50 percent of the state-national gap is closed upon the abandonment of a substantive locality rule. This estimate, however, falls slightly in magnitude and loses statistical significance upon the addition of covariates and state-specific linear trends.

Cardiac Results.-In Table 4, I explore the relationship between national-standard laws and regional convergence in cardiac procedure rates. Panels A and B present results based on two alternative specifications of intensive cardiac treatments: (i) the use of CABG or PTCA and (ii) the use of CABG, PTCA, or cardiac catheterization. In each case, I find evidence of a negative relationship between nationalstandard laws and the percentage absolute deviation between state and national treatment rates, consistent with a convergence effect in which 30-45 percent of the gap between state and national rates is closed upon the change in law, with no indication that any such effect began in the preadoption period (as demonstrated by the estimated "leads" in Tables 4 and 6). Despite stability in the point estimates, the precision of the results varies across specifications.

Panels C, D, and E present the results of similar investigations into convergence in diagnostic rates. The estimated national-standard coefficients presented in panels $\mathrm{C}$ and $\mathrm{D}$ (which take alternative approaches to the calculation of catheterization rates) are consistent with a convergence effect in which roughly 40 percent of the gap between state and national cardiac catheterization rates is closed upon the relevant change in law. I estimate substantially similar results in panel E, where I explore utilization of either cardiac catheterization (invasive) or echocardiogram (noninvasive) within a sample of primary AMI patients.

Finally, in Table 5, I estimate specifications analogous to those of Table 3. For the purposes of brevity, 1 present results for those specifications that identify intensive treatments through the use of CABG or PTCA (though the results generalize to the other cardiac specifications). Consistent with the cesarean results, the signs of the estimated coefficients suggest that the convergence in cardiac rates associated with the change in law occurs from both the initially high- and low-intensity ends of the regional cardiac treatment distribution. Moreover, as with the cesarean analysis, the results of the alternative specifications estimated in columns 3-5, though noisy, further suggest a convergent response. 
Table 4-Relationship between National-Standard Laws and the Percentage Absolute Deviation between State and National Cardiac Procedure Rates

\begin{tabular}{|c|c|c|c|c|c|c|}
\hline & & (1) & $(2)$ & (3) & (4) & (5) \\
\hline \multirow[t]{2}{*}{$\begin{array}{l}\text { Panel A. Treatment: } \\
\text { CABG or PTCA }\end{array}$} & $\begin{array}{l}\text { NS law: two-year } \\
\text { lead dummy }\end{array}$ & $\begin{array}{c}0.67 \\
(8.76)\end{array}$ & $\begin{array}{c}-0.10 \\
(8.18)\end{array}$ & $\begin{array}{l}1.63 \\
(6.84)\end{array}$ & $\begin{array}{c}0.01 \\
(4.57)\end{array}$ & - \\
\hline & $\begin{array}{l}\text { Contemporaneous } \\
\text { dummy }\end{array}$ & $\begin{array}{r}-12.05 \\
(8.40)\end{array}$ & $\begin{array}{c}-14.68 * \\
(8.64)\end{array}$ & $\begin{array}{r}-12.68 \\
(8.38)\end{array}$ & $\begin{array}{r}-11.97 \\
(11.42)\end{array}$ & $\begin{array}{c}-11.97 \\
(11.63)\end{array}$ \\
\hline \multirow[t]{2}{*}{$\begin{array}{l}\text { Panel B. Treatment: } \\
\quad C A B G, P T C A, \text { or C. Cath }\end{array}$} & $\begin{array}{l}\text { NS law: two-year } \\
\text { lead dummy }\end{array}$ & $\begin{array}{c}3.05 \\
(6.33)\end{array}$ & $\begin{array}{c}1.33 \\
(6.83)\end{array}$ & $\begin{array}{c}2.57 \\
(5.93)\end{array}$ & $\begin{array}{c}2.63 \\
(4.17)\end{array}$ & - \\
\hline & $\begin{array}{c}\text { Contemporaneous } \\
\text { dummy }\end{array}$ & $\begin{array}{r}-14.07 * \\
(7.46)\end{array}$ & $\begin{array}{c}-15.87 * * \\
(6.05)\end{array}$ & $\begin{array}{c}-15.39 * * \\
(6.06)\end{array}$ & $\begin{array}{r}-14.52 \\
(8.88)\end{array}$ & $\begin{array}{r}-13.40 \\
(8.47)\end{array}$ \\
\hline \multirow[t]{2}{*}{$\begin{array}{l}\text { Panel C. Diagnostic: } \\
\quad \text { C. Cath (all instances) }\end{array}$} & $\begin{array}{l}\text { NS law: two-year } \\
\text { lead dummy }\end{array}$ & $\begin{array}{c}2.19 \\
(6.38)\end{array}$ & $\begin{array}{r}-0.70 \\
(6.60)\end{array}$ & $\begin{array}{c}0.55 \\
(5.87)\end{array}$ & $\begin{array}{c}-0.31 \\
(4.92)\end{array}$ & - \\
\hline & $\begin{array}{c}\text { Contemporaneous } \\
\text { dummy }\end{array}$ & $\begin{array}{r}-11.68 \\
(7.20)\end{array}$ & $\begin{array}{l}-13.70 * * \\
(5.51)\end{array}$ & $\begin{array}{c}-13.83 * * \\
(5.65)\end{array}$ & $\begin{array}{r}-16.08^{*} \\
(8.38)\end{array}$ & $\begin{array}{r}-16.22 \\
(8.25)\end{array}$ \\
\hline \multirow[t]{2}{*}{$\begin{array}{l}\text { Panel D. Diagnostic: } \\
\quad \text { C. Cath in AMI sample }\end{array}$} & $\begin{array}{l}\text { NS law: two-year } \\
\text { lead dummy }\end{array}$ & $\begin{array}{l}-0.51 \\
(11.06)\end{array}$ & $\begin{array}{l}-4.39 \\
(10.30)\end{array}$ & $\begin{array}{l}-4.81 \\
(10.97)\end{array}$ & $\begin{array}{l}-5.76 \\
(17.93)\end{array}$ & - \\
\hline & $\begin{array}{l}\text { Contemporaneous } \\
\text { dummy }\end{array}$ & $\begin{array}{r}-12.85 \\
(8.83)\end{array}$ & $\begin{array}{c}-13.64 * \\
(7.81)\end{array}$ & $\begin{array}{r}-11.67 \\
(8.10)\end{array}$ & $\begin{array}{l}-13.59 * * \\
(5.51)\end{array}$ & $\begin{array}{c}-16.04 * * \\
(7.52)\end{array}$ \\
\hline \multirow[t]{2}{*}{$\begin{array}{l}\text { Panel E. Diagnostic: C. Cath } \\
\quad \text { or echo in AMI sample }\end{array}$} & $\begin{array}{l}\text { NS law: two-year } \\
\text { lead dummy }\end{array}$ & $\begin{array}{c}4.77 \\
(12.22)\end{array}$ & $\begin{array}{l}-0.89 \\
(10.49)\end{array}$ & $\begin{array}{l}-1.49 \\
(10.81)\end{array}$ & $\begin{array}{c}0.69 \\
(14.58)\end{array}$ & - \\
\hline & $\begin{array}{l}\text { Contemporaneous } \\
\text { dummy }\end{array}$ & $\begin{array}{r}-13.82 \\
(8.36)\end{array}$ & $\begin{array}{c}-13.18^{*} \\
(7.59)\end{array}$ & $\begin{array}{c}-12.65^{*} \\
(7.45)\end{array}$ & $\begin{array}{l}-17.09 * * \\
\quad(7.08)\end{array}$ & $\begin{array}{c}-16.79 * \\
(8.55)\end{array}$ \\
\hline State-year controls? & & No & Yes & Yes & Yes & Yes \\
\hline Additional tort laws? & & No & No & Yes & Yes & Yes \\
\hline State-specific linear trends? & & No & No & No & Yes & Yes \\
\hline
\end{tabular}

Notes: Robust standard errors corrected for within-state correlation in the error term are reported in parentheses. All regressions include state and year fixed effects and are weighted by the number of primary acute myocardial infarction discharges in each state-year cell. Utilization data is from the NHDS.

*** Significant at the 1 percent level.

** Significant at the 5 percent level.

* Significant at the 10 percent level.

\section{B. Neonatal Health Outcomes Analysis}

I next evaluate the consequences of the regional shifts in utilization documented in the above findings. For the purposes of brevity (and in light of the emphasis in the utilization analysis), I focus on the cesarean utilization context. ${ }^{31}$

Marginal Appropriateness.-To evaluate the clinical condition of the marginal mothers receiving a cesarean delivery, I estimate the specification indicated in equation (4) above. In the instrumental-variables specification estimated in panel B of Table 7, I find that the marginal cesarean has a predicted probability of cesarean section (PPC) that is roughly 25 percentage points lower than that of the average

\footnotetext{
${ }^{31}$ Allowing for an observation of those who do and do not receive a cesarean, the delivery subsample easily facilitates an estimation of the clinical appropriateness for surgery. In unreported regressions, I take a similar approach in the cardiac context. Lacking a well-contained subsample of those eligible for surgical intervention, however, I explore the clinical need for intensive cardiac treatment by observing the incidence of the relevant risk factors among the full set of patients in the NHDS records that exceed given ages (e.g., 40 years old, 50 years old, etc.). The results of these unreported regressions indicate evidence of triage in cardiac care at the high-intensity end of the regional cardiac distribution, with weaker evidence of triage at the low-intensity end.
} 
Table 5-Relationship between National-Standard Laws and State Cardiac Procedure (CABG OR PTCA) RATE LEVELS

\begin{tabular}{|c|c|c|c|c|c|}
\hline & \multirow{2}{*}{$\begin{array}{c}\begin{array}{c}\text { States with } \\
\text { below-average } \\
\text { rates }\end{array} \\
(1)\end{array}$} & \multirow{2}{*}{$\begin{array}{c}\text { States with } \\
\text { above-average } \\
\text { rates }\end{array}$} & \multicolumn{3}{|c|}{$\begin{array}{c}\text { Entire sample of states } \\
\text { (above and below } \\
\text { average rates) }\end{array}$} \\
\hline & & & (3) & (4) & $(5)$ \\
\hline National-standard (NS) law dummy & $\begin{array}{c}16.55 \\
(17.22)\end{array}$ & $\begin{array}{c}-18.07^{*} \\
(8.93)\end{array}$ & $\begin{array}{r}-11.86 \\
(8.07)\end{array}$ & - & - \\
\hline NS law $\times$ below average state & - & - & $\begin{array}{c}24.99 \\
(18.12)\end{array}$ & - & - \\
\hline Modified NS law dummy & - & - & - & $\begin{array}{c}12.69 \\
(10.77)\end{array}$ & $\begin{array}{c}13.31 \\
(11.77)\end{array}$ \\
\hline Modified NS law dummy: two-year lead & - & - & - & - & $\begin{array}{c}-1.60 \\
(8.34)\end{array}$ \\
\hline Observations & 611 & 509 & 1,120 & 1,120 & 1,120 \\
\hline
\end{tabular}

Notes: Robust standard errors corrected for within-state correlation in the error term are reported in parentheses. All regressions include state and year fixed effects and a set of state-year controls and state-specific linear time trends. Regressions are weighted by the number of primary acute myocardial infarction discharges in each state-year cell. The regression in column 3 also includes a separate dummy variable indicating whether the state has an initially below-average treatment rate (coefficient omitted). Utilization data is from the NHDS.

*** Significant at the 1 percent level.

** Significant at the 5 percent level.

* Significant at the 10 percent level.

Table 6-Relationship between National-Standard Laws and the Percentage Absolute Deviation between State and National Treatment Rates: Dynamic Regression Results

\begin{tabular}{|c|c|c|c|c|c|c|c|c|}
\hline & $(1)$ & $(2)$ & $(3)$ & $(4)$ & $(5)$ & (6) & (7) & $(8)$ \\
\hline \multicolumn{9}{|c|}{ Coefficient of national-standard law dummy } \\
\hline Three-year lead dummy & $\begin{array}{c}0.91 \\
(4.27)\end{array}$ & $\begin{array}{c}1.39 \\
(3.67)\end{array}$ & $\begin{array}{c}0.94 \\
(3.55)\end{array}$ & $\begin{array}{c}2.59 \\
(2.57)\end{array}$ & $\begin{array}{l}-2.98 \\
(11.34)\end{array}$ & $\begin{array}{l}-7.16 \\
(11.64)\end{array}$ & $\begin{array}{l}-4.95 \\
(10.90)\end{array}$ & $\begin{array}{r}-3.51 \\
(8.94)\end{array}$ \\
\hline Two-year lead dummy & $\begin{array}{c}-1.53 \\
(2.53)\end{array}$ & $\begin{array}{c}-2.05 \\
(2.52)\end{array}$ & $\begin{array}{c}-1.78 \\
(2.63)\end{array}$ & $\begin{array}{c}-2.53 \\
(2.63)\end{array}$ & $\begin{array}{c}0.01 \\
(6.32)\end{array}$ & $\begin{array}{c}2.85 \\
(7.11)\end{array}$ & $\begin{array}{c}3.17 \\
(7.13)\end{array}$ & $\begin{array}{c}1.83 \\
(6.76)\end{array}$ \\
\hline One-year lead dummy & $\begin{array}{c}1.80 \\
(3.35)\end{array}$ & $\begin{array}{c}1.01 \\
(3.40)\end{array}$ & $\begin{array}{c}0.86 \\
(3.42)\end{array}$ & $\begin{array}{c}1.64 \\
(3.37)\end{array}$ & $\begin{array}{l}5.93 \\
(6.45)\end{array}$ & $\begin{array}{c}5.57 \\
(6.19)\end{array}$ & $\begin{array}{c}4.77 \\
(5.79)\end{array}$ & $\begin{array}{c}1.41 \\
(4.90)\end{array}$ \\
\hline $\begin{array}{l}\text { Contemporaneous } \\
\text { dummy }\end{array}$ & $\begin{array}{l}-4.96 * * \\
(2.44)\end{array}$ & $\begin{array}{c}-5.16^{*} \\
(2.63)\end{array}$ & $\begin{array}{c}-5.06 * \\
(2.72)\end{array}$ & $\begin{array}{l}-5.47 * * \\
(2.39)\end{array}$ & $\begin{array}{c}-14.83 \\
(10.26)\end{array}$ & $\begin{array}{r}-17.26^{*} \\
(9.87)\end{array}$ & $\begin{array}{r}-14.88 \\
(9.63)\end{array}$ & $\begin{array}{r}-12.84 \\
(11.20)\end{array}$ \\
\hline $\begin{array}{c}F \text {-statistic (leads } \\
\text { jointly }=0)\end{array}$ & 0.17 & 0.22 & 0.16 & 0.55 & 0.51 & 0.48 & 0.31 & 0.08 \\
\hline Prob $>F(p$-value $)$ & 0.92 & 0.88 & 0.93 & 0.65 & 0.68 & 0.70 & 0.82 & 0.97 \\
\hline $\begin{array}{l}\text { Dependent } \\
\text { variable }\end{array}$ & \multicolumn{4}{|c|}{$\begin{array}{c}\text { Percentage absolute deviation } \\
\text { between state and } \\
\text { national cesarean rates }\end{array}$} & \multicolumn{4}{|c|}{$\begin{array}{l}\text { Percentage absolute deviation between state } \\
\text { and national cardiac treatment rates } \\
\text { (CABG or PTCA) }\end{array}$} \\
\hline State-year controls? & No & Yes & Yes & Yes & No & Yes & Yes & Yes \\
\hline Additional tort laws? & No & No & Yes & Yes & No & No & Yes & Yes \\
\hline $\begin{array}{l}\text { State-specific linear } \\
\text { trends? }\end{array}$ & No & No & No & Yes & No & No & No & Yes \\
\hline
\end{tabular}

Notes: Robust standard errors corrected for within-state correlation in the error term are reported in parentheses. All regressions include state and year fixed effects and are weighted by the number of deliveries used to form the cesarean utilization rate denominators (columns 1-4) or by the number of primary acute myocardial infarction discharges in each state-year cell (columns 5-8). Utilization data is from the NHDS.

*** Significant at the 1 percent level.

** Significant at the 5 percent level.

* Significant at the 10 percent level. 
Table 7-Relationship between Average and Marginal Appropriateness for Cesarean Delivery in Cesarean Sample

\begin{tabular}{|c|c|c|}
\hline & $(1)$ & $(2)$ \\
\hline \multicolumn{3}{|c|}{$\begin{array}{l}\text { Panel A. OLS estimates: effect of the area cesarean rate (logged) on the mean predicted cesarean probability of } \\
\text { the cesarean sample }\end{array}$} \\
\hline Coefficient of $\ln ($ cesarean rate $)$ & $\begin{array}{l}-18.63 * * * \\
\quad(2.45)\end{array}$ & $\begin{array}{l}-33.96 * * * \\
(5.19)\end{array}$ \\
\hline \multicolumn{3}{|c|}{ Panel B. $2 S L S$ results: instrumenting the area cesarean rate (logged) with the modified national-standard law dummy } \\
\hline Coefficient of $\ln ($ cesarean rate $)$ & $\begin{array}{l}-24.87 * * * \\
(9.42)\end{array}$ & $\begin{array}{l}-43.17 * * * \\
(16.31)\end{array}$ \\
\hline Dependent variable logged in panels B and C? & No & Yes \\
\hline Observations & 1,092 & 1,092 \\
\hline
\end{tabular}

Notes: Robust standard errors are reported in parentheses (corrected for within-state correlation in the error term in the case of the OLS regressions). Area cesarean rates are risk-adjusted for age, sex, and the incidence of each of the individual risk factors included in the predicted-cesarean-probability calculation. Regressions are weighted by the number of cesarean deliveries in each state-year cell. All regressions include state and year fixed effects and a set of state-year controls and state-specific linear time trends. Data on cesarean delivery and associated risk factors is from the 1979-2005 NHDS files.

*** Significant at the 1 percent level.

** Significant at the 5 percent level.

* Significant at the 10 percent level.

cesarean delivery. As demonstrated by the log-log specification estimated in column 2, this represents a gap between the average and marginal PPC with a magnitude of roughly 43 percent of the average level.

Table 8 presents the corresponding reduced-form results. As presented in column 4, I find that the modified national-standard indicator, which is otherwise associated with an increase in cesarean rates, is further associated with a 4 percentage-point reduction in the average predicted cesarean probability of the cesarean sample. Moreover, consistent with the utilization findings, I find no such association in the two-year preadoption period (column 5). The signs of the coefficients estimated in column 1 and 2 (bearing in mind the signs of the relationship between national-standard rules and cesarean rates) imply that regional triage occurs at both ends of the regional cesarean distribution, though likely to a stronger degree at the upper end of the distribution (an implication that is further supported by the interaction findings presented in column 3).

These findings suggest that cesarean rates may be at a high enough level that the marginal mothers receiving cesareans are considerably less appropriate for this intensive delivery method and may thus either benefit less, or risk harm, from the intervention. ${ }^{32}$ Of course, it remains possible that the marginal mothers nonetheless benefit somehow from intensive treatment (particularly at the low-intensity end of the distribution), leading to gains in average health outcomes. I turn next to an evaluation of these more direct outcome considerations.

\footnotetext{
${ }^{32}$ In online Appendix C, I discuss the robustness of this finding to the consideration of two additional indications for cesarean delivery that are not available in the NHDS data but that are available over a shorter time frame in the Natality Detail data: low birth weight and preterm delivery.
} 
Table 8-Relationship between National-Standard LaW Adoptions and Predicted Cesarean ProbabiLities (among sample of individual cesarean deliveries)

\begin{tabular}{|c|c|c|c|c|c|}
\hline & \multirow{2}{*}{$\begin{array}{c}\begin{array}{c}\text { States with } \\
\text { below-average } \\
\text { rates }\end{array} \\
(1)\end{array}$} & \multirow{2}{*}{$\begin{array}{c}\begin{array}{c}\text { States with } \\
\text { above-average } \\
\text { rates }\end{array} \\
(2)\end{array}$} & \multicolumn{3}{|c|}{$\begin{array}{c}\text { Entire sample of states } \\
\text { (above and below } \\
\text { average rates) }\end{array}$} \\
\hline & & & (3) & (4) & (5) \\
\hline $\begin{array}{l}\text { National-standard (NS) } \\
\text { law dummy }\end{array}$ & $\begin{array}{l}-2.79 \\
(2.01)\end{array}$ & $\begin{array}{l}6.82 * \\
(3.38)\end{array}$ & $\begin{array}{c}5.97 \\
(3.21)\end{array}$ & - & - \\
\hline $\begin{array}{l}\text { NS law } \times \text { below average } \\
\text { state }\end{array}$ & - & - & $\begin{array}{l}-8.98 * * \\
(3.48)\end{array}$ & - & - \\
\hline $\begin{array}{l}\text { Modified NS law } \\
\text { dummy }\end{array}$ & - & - & - & $\begin{array}{l}-3.77 * * \\
(1.60)\end{array}$ & $\begin{array}{l}-4.03 * * * \\
(1.43)\end{array}$ \\
\hline $\begin{array}{l}\text { Modified NS law } \\
\text { dummy: two-year lead }\end{array}$ & - & - & - & - & $\begin{array}{c}0.71 \\
(1.69)\end{array}$ \\
\hline Observations & 41,419 & 73,268 & 114,687 & 114,687 & 114,687 \\
\hline
\end{tabular}

Notes: Robust standard errors corrected for within-state correlation in the error term are reported in parentheses. All regressions include state and year fixed effects and a set of state-specific linear time trends and various individual and state-year controls, along with controls for the average state-year incidence rates (out of the full delivery sample) for each of the individual risk factors used in the PPC calculation. The regression in column 3 also includes a separate dummy variable indicating whether the state has an initially below-average cesarean rate (coefficient omitted). Cesarean data is from the 1979-2005 NHDS files.

*** Significant at the 1 percent level.

** Significant at the 5 percent level.

* Significant at the 10 percent level.

Average Neonatal Outcomes.-In panel A of Table 9, I estimate the association between national-standard laws and the percentage absolute deviation between state and national means for several neonatal outcome measures from the National Vital Statistics files (e.g., mean Apgar scores). I find no evidence to suggest that the convergence in cesarean rates is accompanied by corresponding convergence in neonatal outcomes (if anything, the confidence bounds suggests some divergence) and thus no evidence to suggest that changes in the intensity of cesarean utilization generally lead to corresponding changes in neonatal health. ${ }^{33}$ This implication is consistent with the ordinary least squares (OLS) estimates presented in panel A of Table C2 in online Appendix C. Drawing on an arguably exogenous source of variations in cesarean rates, these findings, in connection with the triage results, lend support to a story of "flat-of-the-curve" medicine, in which additional care within regions generates little additional gains.

Moreover, panels B and C of Table C2, which estimate the OLS specification separately for initially high cesarean states and initially low states, present no substantial evidence to suggest that increases in cesarean intensities have differential effects at each end of the cesarean distribution. In connection with the triage findings in Table 8, these findings imply that both the increase in cesarean rates in some states following national-standard adoptions and the decrease in other states may not be associated with changes in prevailing neonatal health measures (though the

\footnotetext{
${ }^{33}$ Considering the means of the respective dependent variables (as reported in Table 1), the point estimates in columns 2, 4, and 6 suggest a widening of the gap between state and national outcomes of roughly 35 percent, 9 percent, and 20 percent, respectively.
} 
Table 9-Relationship between National-Standard LaWs and the Percentage Absolute Deviation between State and National Mean Neonatal Health Outcomes

\begin{tabular}{|c|c|c|c|c|c|c|}
\hline & \multicolumn{2}{|c|}{$\begin{array}{l}\text { Five-minute Apgar } \\
\text { scores }\end{array}$} & \multicolumn{2}{|c|}{$\begin{array}{l}\text { "Good" five-minute } \\
\text { Apgar scores }\end{array}$} & \multicolumn{2}{|c|}{$\begin{array}{c}\text { 28-day neonatal } \\
\text { mortality rate }\end{array}$} \\
\hline & (1) & (2) & (3) & (4) & (5) & (6) \\
\hline $\begin{array}{l}\text { Coefficient of national-standard } \\
\text { law dummy }\end{array}$ & $\begin{array}{c}0.24 \\
(0.15)\end{array}$ & $\begin{array}{l}0.29 * * \\
(0.13)\end{array}$ & $\begin{array}{l}0.08^{* *} \\
(0.04)\end{array}$ & $\begin{array}{c}0.02 \\
(0.04)\end{array}$ & $\begin{array}{c}-1.15 \\
(3.49)\end{array}$ & $\begin{array}{c}3.28 \\
(3.71)\end{array}$ \\
\hline $\begin{array}{l}\text { Controls and state-specific } \\
\text { linear trends? }\end{array}$ & No & Yes & No & Yes & No & Yes \\
\hline Observations & 1,257 & 1,237 & 1,257 & 1,237 & 1,344 & 1,317 \\
\hline
\end{tabular}

Notes: Robust standard errors corrected for within-state correlation in the error term are reported in parentheses. All regressions included state and year fixed effects and are weighted by the number of deliveries associated with each state-year cell. Data on Apgar scores is from the 1978-2004 Natality Detail Files. Data on neonatal deaths is from the 1989-2004 Vital Statistics Mortality records.

*** Significant at the 1 percent level.

** Significant at the 5 percent level.

* Significant at the 10 percent level.

triage findings are weaker in the low-intensity end of the cesarean distribution). Considering that cesareans are generally costlier than vaginal deliveries (Russo, Weir, and Steiner 2006), national-standard adoptions may thus lead to both welfare losses in some regions and welfare gains in others.

\section{Discussion and Conclusion}

The divergent regional pathways that we have long observed in medical practices took root during periods of time in which medical liability rules, by their very terms, encouraged the maintenance of local customs. By demonstrating that physician practices converged regionally when states abandoned such rules, the above findings suggest that the law may have indeed facilitated the proliferation of divergent practices. In addition to shedding light on an historical puzzle, the analysis suggests that even greater standardization in medical liability law may lead to yet further reductions in practice disparities. Of course, if optimal treatment rates do indeed lie closer to the low-intensity end of the utilization distribution, greater welfare gains may be achieved if those laws pushing for greater uniformity in practices are coupled with additional reforms aimed at reducing general over-utilization tendencies.

The above analysis also offers a perhaps more fundamental contribution by demonstrating the empirical relevancy of malpractice standard laws. The literature to date has focused largely on exploring the relationship between practice intensities and variations in the underlying level of malpractice pressure. Under these traditional investigations, it is unclear whether liability pressure causes physicians to alter their practices in a more general, unguided sense or whether it causes physicians to more strongly adhere to specific clinical standards expected of them under the law. The present study allows for an investigation into responses of this latter type by focusing more directly on the structure of liability rules. The findings are perhaps encouraging in demonstrating that the law holds the potential to deter particular clinical practices. They are perhaps discouraging, however, in suggesting that the law may impose a source of friction on medical practice innovations, insofar 
as the findings may imply that liability rules based on custom have "bite" and thus discourage deviations from custom.

\section{REFERENCES}

-Acemoglu, Daron, and Amy Finkelstein. 2008. "Input and Technology Choices in Regulated Industries: Evidence from the Health Care Sector." Journal of Political Economy 116 (5): 837-80.

-Adams, E. Kathleen, and Stephen Zuckerman. 1984. "Variation in the Growth and Incidence of Medical Malpractice Claims." Journal of Health Politics, Policy and Law 9 (3): 475-88.

-Baicker, Katherine, Kasey S. Buckles, and Amitabh Chandra. 2006. "Geographic Variation in the Appropriate Use of Cesarean Delivery." Health Affairs 25 (5): w355-w67.

-Baicker, Katherine, Elliot S. Fisher, and Amitabh Chandra. 2007. "Malpractice Liability Costs And The Practice Of Medicine In The Medicare Program." Health Affairs 26 (3): 841-52.

- Bertrand, Marianne, Esther Duflo, and Sendhil Mullainathan. 2004. "How Much Should We Trust Differences-in-Differences Estimates?" Quarterly Journal of Economics 119 (1): 249-75.

Blumstein, James. 2006. "Medical Malpractice Standard-Setting: Developing Malpractice 'Safe Harbors' as a New Role for QIOs?" Vanderbilt Law Review 59 (4): 1017-49.

-Chandra, Amitabh, and Douglas O. Staiger. 2007. "Productivity Spillovers in Healthcare: Evidence From the Treatment of Heart Attacks." Journal of Political Economy 115 (1): 103-40.

-Currie, Janet, and W. Bentley MacLeod. 2008. "First Do No Harm? Tort Reform and Birth Outcomes." Quarterly Journal of Economics 123 (2): 795-830.

-Cutler, David M., and Louise Sheiner. 1999. "The Geography of Medicare." American Economic Review 89 (2): 228-33.

Danzon, Patricia. 1984. "The Frequency and Severity of Medical Malpractice Claims." Journal of Law and Economics 27 (1): 115-48.

-Frakes, Michael. 2013. "The Impact of Medical Liability Standards on Regional Variations in Physician Behavior: Evidence from the Adoption of National-Standard Rules: Dataset." American Economic Review. http://dx.doi.org/10.1257/aer.103.1.257.

-Gruber, Jonathan, and Daniel M. Hungerman. 2008. "Church versus the Mall: What Happens When Religion Faces Increased Secular Competition." Quarterly Journal of Economics 123 (2): 831-62.

-Gruber, Jonathan, Phillip Levine, and Douglas Staiger. 1999. "Abortion Legalization and Child Living Circumstances: Who is the 'Marginal Child?"” Quarterly Journal of Economics 114 (1): 263-91.

-Gruber, Jonathan, and Maria Owings. 1996. "Physician Financial Incentives and Cesarean Section Delivery." The RAND Journal of Economics 27 (1): 99-123.

-Kessler, Daniel, and Mark McClellan. 1996. "Do Doctors Practice Defensive Medicine?" Quarterly Journal of Economics 111 (2): 353-90.

National Center for Health Statistics (NCHS). 1977-2005. "National Hospital Discharge Survey." Centers for Disease Control and Prevention (accessed January 31, 2012).

National Center for Health Statistics (NCHS). 1978-2004. "Data File Documentations, Detail Natality." Centers for Disease Control and Prevention (accessed January 1, 2009).

National Center for Health Statistics (NCHS). 1977-2004. "Data File Documentations, Multiple Cause of Death." Centers for Disease Control and Prevention (accessed January 1, 2009).

-Phelps, Charles E. 1992. "Diffusion of Information in Medical Care." Journal of Economic Perspectives 6 (3): 23-42.

Phelps, Charles E., and Cathleen Mooney. 1993. "Variations in Medical Practice Use: Causes and Consequences." In Competitive Approaches to Health Care Reform, edited by Richard J. Arnould, Robert F. Rich, and William D. White, 140-78. Washington, DC: The Urban Institute Press.

Russo, C. Allison, Lauren Weir, and Claudia Steiner. 2006. "Hospitalizations Related to Childbirth, 2006." Healthcare Cost and Utilization Project Statistical Brief 71.

-Waters, Teresa M., Peter P. Budetti, Gary Claxton, and Janet P. Lundy. 2007. "Market Watch: Impact of State Tort Reforms on Physician Malpractice Payments." Health Affairs 26 (2): 500-09.

-Wennberg, John E. 1984. "Dealing With Medical Practice Variations: A Proposal for Action." Health Affairs 3 (2): 6-32.

Wennberg, John E., and Megan McAndrew Cooper, eds. 1999. The Quality of Medical Care in the United States: A Report on the Medicare Program. The Dartmouth Atlas of Health Care in the United States. Hanover, NH: The Trustees of Dartmouth College. 